\title{
UPAYA PEMBIMBING ASRAMA DALAM MENINGKATKAN KEMANDIRIAN PESERTA DIDIK TUNANETRA DI ASRAMA SLBN A CITEUREUP CIMAHI
}

\author{
Ajeng Amelia*, E. Ehan, Riksma Nurahmi Rinalti Ahlan \\ Departemen Pendidikan Khusus, Fakultas Ilmu Pendidikan, Universitan Pendidikan \\ Indonesia, Bandung, Indonesia \\ *ameliaajeng98@gmail.com
}

\begin{abstract}
This study aims to find out how dorm guide increased independece especially independence value of visual impairment students who started their teens. Independence value is the ability to interpret the principles of right and wrong, important and not important. Trough their dorm guide who replace their parents role, students at SLBN A Citeureup Cimahi dorm trained to obey the rules at dorm so that students could be discipline and responsible. The method of this study is used qualitative descriptive and data collected technique used interview and observation. The subject of this study is two dorm guide and students 14-15 years old teenager. The result of this study indicated that dorm guide arranged program until implementation trough rules who approved by visual impairment students. Dorm guide SLBN A Citeureup Cimahi be able to face and pursue problems that affecting their independence, one of them by mantaining communication, not by violence and always apply the approved punishment.
\end{abstract}

Keywords: Dormitory supervisors, Independence of value, and Visual impairment students

\begin{abstract}
ABSTRAK
Penelitian ini dilakukan bertujuan untuk mengetahui bagaimana pembimbing asrama dalam meningkatkan kemandirian khususnya kemandirian nilai para peserta didik tunanetra yang memasuki usia remaja. Kemadirian nilai merupakan kemampuan memaknai seperangkat prinsip tentang benar dan salah, tentang apa yang penting dan apa yang tidak penting. Melalui pembimbing asrama yang menggantikan orang tua mereka, peserta didik di Asrama SLBN A Citeureup Cimahi diberi pelatihan untuk mentaati peraturan yang ada diasrama agar para peserta didik disiplin dan bertanggung jawab. Metode yang digunakan dalam penelitian ini adalah deskriptif kualitatif dan pengambilan data dilakukan dengan cara wawancara dan observasi. Subjek penelitian terdiri dari dua orang pembimbing asrama dan peserta didik tunanetra yang berusia remaja 14-15 tahun. Hasil penelitian menunjukan bahwa pembimbing asrama menyusun pembuatan program sampai pelaksanaannya dengan membuat peraturan yang disepakati oleh semua peserta didik tunanetra yang berasrama. Pembimbing asrama SLBN A Citeureup Cimahi mampu menghadapi dan mengupayakan permasalahan yang mempengaruhi kemandirian mereka, salah satunya dengan menjaga hubungan komunikasi, tidak dengan kekerasan dan selalu menerapkan sanksi yang telah disepakati.
\end{abstract}

Kata Kunci: Upaya pembimbing asrama, kemandirian nilai dan peserta didik tunanetra. 


\section{JASSI_anakku Volume 20 Nomor 2, Desember 2020}

\section{Pendahuluan}

Kemandirian pada remaja didasarkan kepada pertimbangan bahwa bagi remaja, pencapaian kemandirian merupakan dasar untuk menjadi orang dewasa yang sempurna. Kemandirian merupakan hal yang sangat terpenting untuk dimiliki oleh remaja dan merupakan salah satu tugas perkembangannya dalam menuju kedewasaan. Menurut Steinberg mengatakan bahwa bagi kebanyakan remaja, membangun rasa kemandirian sama pentingnya dengan menjadi dewasa sebagaimana membangun rasa identitas(Imas, 2009). Menjadi orang yang mandiri ,orang yang memerintah sendiri adalah salah satu tugas perkembangan mendasar pada perkembangan saat remaja.

Perilaku kemandirian terkadang ditafsirkan sebagai pemberontakan karena pada kenyataannya remaja yang memulai mengembangkan kemandirian sering kali diawali dengan memunculkan perilaku yang tidak sesuai dengan aturan keluarga Steinberg (dalam Nandang Budiman 1995:286). Steinberg (2016:288) mengemukakan kemandirian menjadi tiga bagian, kemandirian emosi (emotional autonomy), kemandirian perilaku (behavioral autonomy) dan kemandirian nilai (cognitive autonomy atau yang sering disebut value autonomy).

Menurut Puguh Setiyoko (2015:2-4) Ketika masa peralihan menuju remaja, tunanetra memiliki perubahan yang mempengaruhi perkembanagan emosi. Perkembangan emosi pada remaja tunanetra memiliki hambatan, terutama disebabkan keterbatasan dalam penglihatannya maka berpengaruh pada keterbatasan kehidupan sehari-hari. Memasuki masa remaja pada tunanetra pun mempengaruhi pada perkembangan sosial. Seperti halnya dalam kehidupan sosial di masyarakat, anak akan berhadapan dengan ukuran-ukuran yang menentukan baik-buruk suatu nilai dan tingkah laku. Tunanetra memiliki ukuran-ukuran terbatas dalam menentukan baikburuk, benar salah dari suatu tingkah laku saat akan bertindak.

Berdasarkan fakta yang ada di lapangan, peserta didik tunanetra Asrama SLBN A Citeureup diberi pelatihan kedisipilinan oleh pembimbing asrama berupa bangun tidur sesuai dengan aturan karena akan melakukan solat subuh berjamaah di masjid, melakukan piket asrama, sarapan dengan tertib, memakai handphone ketika waktu 


\section{JASSI_anakku Volume 20 Nomor 2, Desember 2020}

luang dan mengumpulkan handphone sesuai batasan waktu yang ditentukan. Terdapat batasan-batasan yang terjadi pada pembimbing asrama dengan peserta didik yaitu, pembimbing asrama laki- laki lebih membatasi dengan hal yang mengenai dengan peserta didik perempuan begitu pun sebaliknya dan selanjutnya dengan menjaga etika satu sama lain. Walaupun terdapat batasan tidak menyurutkan kedekatan diantara pembimbing asrama dengan peserta didik.

Pembimbing asrama dalam membimbing peserta didik tunanetra Asrama SLBN A Citeureup memiliki beberapa kendala salah satunya mengahadapi pola pikir anak yang sudah memasukin masa remaja. Masalah yang terjadi pada peserta didik tunanetra diusia remaja di Asrama SLBN A Citeureup yaitu dalam prilaku anak seperti membantah intruksi untuk solat, mengaji dan mentaati aturan di asrama. Pembimbing asrama memahami betul bahwa salah satu penyebab penyimpangan prilaku adalah tahap masa remaja yang sedang di alami siswa.

Kemandiri sebuah tuntutan yang dilakukan dan harus dimiliki oleh setiap individu tanpa kecuali peserta didik tunanetra. Peran pembimbing asrama sebagai pengganti orangtua harus menanamkan nilai mana yang benar untuk dilakukan dan mana yang seharusnya tidak dilakukan, sehingga akan mengarahkan kepada sebuah kemandirian nilai. Maka dari itu jika kemandirian ditanamkan dari sejak dini oleh keluarga maupun orang terdekatnya, mereka akan melakukan kegiatan secara mandiri dalam sehari hari terutama dalam urusan yang menyangkut mana yang benar mana dan salah serta mana yang boleh dilakukan dan yang tidak boleh dilakukan saat bertindak.

\section{Metode}

Jenis penelitian yang digunakan dalam penelitian ini adalah kualitatif. Penelitian kualitatif menurut Sugiyono (2017:15) metode kualitatif adalah metode yang berlandaskan pada filsafat postpositivisme, digunakan untuk meneliti pada kondisi obyek yang alamiah, (sebagai lawannya adalah eksperimen) dimana peneliti adalah sebagai instrument kunci, pengambilan sampel sumber data dilakukan secara purposive dan snowbaal, teknik pengumpulan dengan tringgulasi (gabungan), analisis 


\section{JASSI_anakku Volume 20 Nomor 2, Desember 2020}

data bersifat induktif/kualitatif, dan hasil penelitian kualitatif lebih menekankan makna dari pada generalisasi.

Subjek dalam penelitian ini adalah kepada peserta didik tunanetra yang memasuki remaja pada umur 13-15 tahun dan para pembimbing asrama. Selanjutnya instrument penelitian sederhana dikembangkan setelah fokus penelitian jelas. Instrument yang dibuat yaitu pedoman wawancara dan observasi untuk mengungkapkan bagaimana upaya pembimbing asrama dalam meningkatkan kemandirian nilai peserta didik tunanetra di SLBN A Citeureup Cimahi.

Selanjutnya dalam pengujian keabsahan data, peneliti menggunakan uji dependability dengan mengaudit keseluruhan proses penelitian. Peneliti melakukan pengujian ini dengan cara melakukan bimbingan dengan dosen pembimbing skripsi untuk mengaudit keseluruhan data dan keseluruhan aktivitas yang dilakukan oleh peneliti. Kemudian dalam menganalisis data ada beberapa langkah-langkah yang dilakukan, pertama reduksi data, pada tahap ini peneliti melakukan menyelesksi data, menyederhanakan data yang sesuai dengan tujuan penelitian. Kedua penyajian data, disini peneliti melakukan pengembangan sebuah deskripsi informasi yang telah tersusun untuk menarik kesimpulan dan pengambilan tindakan. Penyajian data yang digunakan pada langkah ini adalah berbentuk teks naratif berisi program, pelaksanan, kesulitan pembimbing asrama dan upaya yang dilakukan oleh pembimbing asrama. Ketiga verifikasi data, tahap penarikan kesimpulan ini masih bersifat sementara. Untuk meverifikasi data, peneliti melakukan verifikasi kepada kedua pembimbing asrama dan tiga peserta didik tunanetra yang berusia 13-15 tahun.

\section{Hasil dan Pembahasan}

Berdasarkan hasil wawancara bersama kedua pmbimbing asrama. pertama yang diawali untuk penyusunan program peraturan yang akan membantu kemandirian khususnya kemandirian nilai yang dibuat di awal tahun ajaran baru, yaitu dengan mengumpulkan semua peserta didik untuk mendiskusikan perihal pertaran yang akan dibuat dan sanksi-sanksi yang disepkati oleh kedua belah pihak. Terkadang ada saja peserta didik yang berbeda pandanagan, tetapi untuk mencari jalan keluarnya 


\section{JASSI_anakku volume 20 Nomor 2, Desember 2020}

pembimbing mempertimbangkan kembali agar peraturan tersebut tidak memberatkan anak-anak. Tujuan dari adanya program peraturan di asrama ini yaitu melatih kemandiriannya, tanggung jawab dan kedisiplinan. semua tujuan itu sudah mulai terlihat dalam diri peserta didik tunanetra walaupun semua itu butuh proses.

Materi yang diterapkan kedalam peraturan yang ada kedua pembimbing mengatakan, pendidikan kewarganegaraan dan pendidkan agama islam bisa jadi acuan. Pendidikan kewarganegaraan didalamnya terdapat pembahasan mengenai norma-norma tingkah lakumanusia dan sedangkan pendidikan agama islam terdapat pembahasan perilaku yang dibenarkan yang tidak dibenarkan ketika akan melakukan suatu hal.

Strategi agar peraturan itu terlaksanakan oleh peserta didik, pembimbing asrama memperbanyak contoh dari pada ucapan. Penegasan dalam sanksi menjadi sebuah startegi lain yang digunakan kepada peserta didik. Kedua strategi tersebut sejauh ini berhasil diterapkan kepada peserta didik bahkan mereka sudah bisa mengakui kesalahannya sendiri tanpa diingatkan.

Dari hasil wawancara metode yang dugunakan para pembimbing kepada peserta didik yaitu dengan menggunakan kasih sayang. Pembimbing mengusahakan tidak pernah sampai berkata kasar dan berbicara keras kepada para peserta didik tunanetra.. Selain metode kasih sayang yang digunakan, metode dengan cara menanamkan kesadaran diri dalam diri anak. Kedua metode itu sangat membantu para pembimbing asrama, bisa membuat peserta didik mematuhi peraturan yang ada dan mengerjakan aktivitas tanpa bantuan pembimbing lagi. Hal tersebut sejalan dengan yang diungkapkan Muhammad Darwis Dasopang (dalam J.R David, 1976) "bahwa pengertian metode adalah cara untuk mencapai sesuatu dan metode menjadi salah satu unsur dalam strategi belajar mengajar".

Seperti yang dikemukakan oleh Muhammad Darwis Dasopang (dalam Siddik,hlm 142) bahwa "media yang berfungsi sebagai alat bantu untuk memperlancar penyelengaraan pembelajaran aga lebih efisien dan efektif dalam mencapai tujuan pembelajaran". Maka untuk memperlancar pelaksanaan program peraturan untuk meningkatkan kemandiria khususnya kemandirian nilai, menurut 


\section{JASSI_anakku volume 20 Nomor 2, Desember 2020}

kedua pembimbing dari hasil wawancara. Media yang digunakan itu mengikuti kegiatan situasi dan kondisi yang sedang peserta didik lakukan

Awal persiapan agar peserta didik harus mempunyai target yang akan dicapai diasrama itu akan seperti apa, ketika target sudah didapatkan maka pembimbing asrama mengarahkan peserta didik sesuai kemauan mereka. Menurut pembimbing, asrama perlu merubah kebiasaan kearah yang lebih dan yang paling penting menumbuhkan kesabaran dalam diri.

Pihak asrama tidak perlu mendapatkan perizinan ketika akan mebuat peraturan diasrama. Karena itu urusan intern. Terdapat pembimbing asraama yang menerapkan paksaan kepada peserta didik tuannetra untuk mengikuti pelaksanaan peraturan meningkatkan kemandirian khussunya kemandirian nilai mereka yang telah dibuat. Karena jika tanpa adanya paksaan peraturan akan seperti karet tidak akan ada wibawanya. Semua itu demi kebaikan para peserta didik. Tetapi terdapat pandangan lain dari pembimbing yang lain bahwa tidak adanya pemaksaan agar para peserta didik mau mengikuti peraturan yang telah dibuat.karena perlahan para peserta didik mau mengikuti praturan yang ada dan menjalankan sanksi ketika mereka melakukan kesalahan.

Hubungan komunikasi yang nyaman dan menganggap mereka sebagai anak sendiri bisa membantu menjalankan program peraturan yang telah dibuat, jadi peserta didik mengikuti perutaran yang ada. Selain itu juga pandangan dari peserta didik dengan adaya peraturan diasrama sejauh ini diterima karena sudah ada kesepakatan diawal walaupun ada saja peserta didik yang menggerutu ketika melakukan perintah dari pembimbing.

Mengevaluasi hasil peserta didik untuk menilai keberhasilnya, pembimbing asrama mengatakan jika peserta didik sudah berada dalam koridornya sendiri. Seperti kemandirian,kedisiplinan dan tanggung jawabnya sudah tertanam dalam diri mereka. Selain itu juga menilai pencapaian peserta didik dilihat dari perubahan sehari-harinya. Jika peserta didik masih melakukan kesalahn terus menerus diberi sanksi dan bimbingan. Menurut pembimbing diasraama jika program ini tidak akan berhasil pembimbing akan mengumpulkan peserta didik kembali dan mencari jalan keluar 


\section{JASSI_anakku Volume 20 Nomor 2, Desember 2020}

agar ada pengertian dari peserta didik selain itu juga agar peraturan tersebut mau dilakukan dan diterapkan di asrama. Hal ini selaras seperti menurut Siswanto (2010:101) bahwa Evaluasi dirancang guna memberikan informasi mengenai hasil karya orang yang dinilai dan orang yang menilai. Secara umum evaluasi ini memiliki tujuan antara lain untuk mencapai kesimpulan yang dapat memberikan pertimbangan mengenai hasil karya tersebut serta untuk mengembangkan karya tersebut melalui program. Untuk keberhasilan para peserta didik tidak ada berupa catatan khsusus maupun dimasukan kedalam rapor sekolah peserta didik tunanetra mengenai selama menjalankan peraturan yang mereka jalani selama diasrama.

Sikap remaja tunanetra yang memasuki usia remaja lebih sensitive mudah tersinggung dan selalu membawa perasaan. Antara peserta didik dengan pembimbing sering kali terjadi salah pengertian dan peserta didik yang memasuki usia remaja sedang masanya ingin serba mencoba dan mengeksplor. Tidak adanya peserta didik yang mmpunyai amarah yang tempramental, karena pembimbing asrama selalu menguatkan sanski dan memang tidak akan meneria peserta didik yang amarah yang memliki tempramental karena takut berdampak buruk kepada pesrta didik yang lain.

Ada perubahan amarah mereka ketika peserta didik masih di umur kanak-kanak menuju dewasa. Ketika masih kanak-kanak amarah mereka itu masih bisa terkontrol sedangkan ketika sudah memasuki usia remaja karena mereka selalu membawa perasaan pembimbing asrama harus lebih hatih-hati dalam menghadapinya walaupun sejauh ini masih bisa terkontrol juga dan pembimbing memakluminya karena peserta didik sedang dalam masa ingin mencoba segala hal.

Menunjukan cara berpikir peserta didik tunanetra tidak memiliki permasalahan yang kompleks. Para peserta didik tunanetra sudah mengetahui mana yang boleh dilakukan dan mana yang tidak boleh dilakukan. Pembimbing asrama mengatakan, ada perubahan dalam cara berpikir walaupun tidak secara signifikan kepada peserta didik tunanetra dari usia kanak-kanak ke masa remaja.

Hubungan peserta didik dengan para pembimbing terjalin komunikasi yang baik. Para pembimbing asrama menganggap peserta didik sebagai anaknya sendiri dan para pesrta didik menganggap pembimbing sebagai pengganti orang tua mereka. 


\section{JASSI_anakku Volume 20 Nomor 2, Desember 2020}

Pembimbing asrama pun sudah menerima mereka apa adanya dari awal mereka masuk dan lebih berhati-hati dibandingkan ke anak kandung sendiri.

Upaya yang dilakukan pembimbing asrama ketika terdapat sikap peserta didik yang melenceng dari peraturan, mereka segera mengambil tindakan yang tegas. Selain itu juga pembimbing asrama melakukan pemanggilan dan menasihati peserta didikt karena meminimalisir contoh yang tidak baik kepada didik yang lainnya. Jika diberi kesempatan tidak ada perubahan pembimbing mengembalikan ke orang tua atau mencari sekolah yang cocok untuk merubah sikapnya.

Tidak ada peserta didik yang memiliki amarah yang tempramental. Tetapi pembimbing asrama memiliki upaya jika kedepannya terdapat peserta didik yang memiliki amarah yang tempramental, yaitu selalu menekankan sanksi yang telah dibuat dan disepakati oleh peserta didik, selalu menanamkan kesadaran diri dan paling utama selalu memberi nasihat.

Upaya menghadapi permasalahan dari cara berpikir peserta didik yang memasuki usia remaja yaitu dengan penekanan agama ke dalam diri peserta didik sangat diutamakan agar berperilaku yang semestinya dan berpikir dengan akal sehat. Hal tersebut selaras dengan pemyataan Fuad Ahmad Faozan dkk (dalam Sanjaya, 2013:27) bahwa "Tugas pembimbing asrama adalah menjaga, mengarahka dan membimbing". Selain itu juga para pembimbing nselalu memberikan hal positif kepada para peserta didik. menurut pembimbing asarama pun memberikan semangat bahwa mereka itu berguna dan layak seperti anak pada umumnya agar tidak memiliki pemikiran rasa minder dalam diri mereka.

Upaya menangani hubungan antara pembimbing dan peserta didiik yaitu dengan menjalin komunaksi yang baik dengan peserta didik. Pembimbing asrama diusahakan harus menjaga tutur kata agar tiak mengluarkan kata kasar dan keras kepada peserta didik. Selain itu juga pembimbing menjadi tempat sharing para peserta didik tunanetra dan selau bersikap adil sehingga para pesrta didik sangat mengahrgai para pembimbing asrama. Seluruh kegaiatan sekecil apapun di asrama, peserta didik selalu dalam pantauan para pembimbing. 


\section{JASSI_anakku Volume 20 Nomor 2, Desember 2020}

\section{Kesimpulan}

Program belum dibuat dalam bentuk dokumen dan dibuat dengan kesepakatan para peserta didik tunanetra. Jika terdapat perbedaan pendapat kembali dirembukan dan mencari jalan keluar bersama. Tujuan menumbuhkan tanggung jawab,kemandirian dan kedisiplinan. Dalam program peraturan diaplikasikan materi pendidikan kewarganegaraan dan pendidikan agama islam karena kedua materi tersebut mengajarkan baik dan buruk saat berprilaku. Strategi yang digunakan memperbanyakan contoh kepada peserta didik tunanetra. Agara program berjalan dengan baik, pembimbing menggunakan metode kasih sayang dan para pembimbing menanamkan kesadaran diri dalam peserta didik. ketika program dijalankan terdapat media yang duganakan oleh peserta didik, media tersebut menyesuaikan sesuai kebutuhan dan yang mampu menunjang mereka.

Persiapan yang dilakukan untk melaksanakn program sebelumnya peserta didik harus mempunya target dalam hidup mereka yang nantinya target tersebut akan di arahkan oleh para pembimbing asarama. Dalam pelaksanaan program tidak perlu izin kepada pihak sekolah dan agar pelaksanaan program berjaln dengan baik terdapat pembimbing melakukan paksaan kepada peserta didik agar mematuhi peraturan yang ada selain itu selalu menjaga hubungan komunikasi yang baik antra pembimbing dan peserta didik. hasil evaluasi peserta didik tunanetra mengenai meningkat atau tidaknya kemandirian mereka tidak dibuat secara tertulis, tetapi dilihat apakah peserta didik sudah berada dikoridonya atau tidak ada peningkatan sama sekali.

Pembimbing asrama dalam menyikapi permaslahan pesrta didik tunanetra dalam sikap,amarah,cara berpikir dan membangun hubungan dengan mereka, sejauh ini para pembi,bing asrama belum menemukan permasalahan yang berat dan masih bisa menghadapi permaslaahan yang ada. contoh permasalahan yang ada dalam sikap mereka yaitu menghadapi pesreta didik yang mudah tersinggung dan memasuki masa baligh yang mengakibtakan mereka lebih sensitif.. Amarah merekapun hanaya sebatas menggerutu tidak sampai menyebabkan hal yang membahayakan yang lainnya dan tidak ada peserta didik yang tempramental. Hanya saja masih terdapat peserta didik yang suka membohong haid nyatanya tidak dan mengulur-ngulur waktu 


\section{JASSI_anakku Volume 20 Nomor 2, Desember 2020}

solat. Cara berpikir merekapun sudah mengarah mana yang baik dan buruk ketika berprilaku, karena pembimbing asrama menanamkan manusia berakhlak. Untuk menjaga hubungan yang baik dengan peserta didik.

Upaya yang dilakukan untuk menyikapi permaslah yang ada para pembimbing asrama lebih tegas dalam mengambil tindakan ketika peserta didik melalaikan tugas dan peraaturan yang telah disepakati. Para pembimbing asrama citeureup lebih menekankan sanksi yang telah disepakti saat pembutan program peraturan. Selain itu juga penekanan agama menjadi nonor satu yang dilakukan pembimbing asrama kepada peserta didik diasrama, bertutur kata yang baik, tidak mengeluarkan kata kasar, selalu menjaga hubungan yang baik dengan peserta didik, pembimbing selalu menghargai mereka sebagaimana mestinys dan sellau memantau sekecil appaun kegiatan mereka di asrama. Tetapi jika tidak ada perubahan, pembimbing asrama siap mengembalikan peserta didik kepada orang tua dan ahli yang bisa mengupayakan permaslaahn para peserta didik tunanetra di asrama.

\section{Referensi}

Faozan, F. A., Maya, R., \& Sarifudin, S. (2019). Peran Pembimbing Asrama (Musyrif) Dalam Meningkatkan Disiplin Beribadah Santri Di Ma'had Huda Islami (Mhi) Tamansari Kabupaten Bogor. Prosa PAI: Prosiding Al Hidayah Pendidikan Agama Islam, 2(1), 78-88.

Aprilia, I. D., \& Biasa, J. P. L. (2009). Pengembangan Kemandirian Remaja Tunarungu. JASSI Anakku, 8(2), 177-127.

Siswanto. (2010). Pengantar Manajemen. Jakarta: Bumi Aksara.

Sugiyono, S. (2017). Metode Penelitian Pendidikan Pendekatan Kuantitatif dan Kualitatif. Bandung: Alfabeta 